\title{
Convictions of the Innocent
}

Dortell Williams and Tony Majoy

Innocent men wrongfully convicted are countless.

- Max Hirschberg, Convicting the Innocent

66 T'm innocent ... really!" Almost clichéd, it is a running joke both in and out of prison. Everyone in prison is innocent, let them tell it. Yet, a surprising number of studies reveal that many are, indeed, really innocent. In the unrelenting clamour for revenge against prisoners, it is this particularly vulnerable group, which falls forgotten to America's war on crime: the wrongfully convicted.

Untold billions flow into the black hole of prison expansion, while funds to represent indigent citizens are drastically diminished. This translates into less case investigation, less resources for trial preparation and inadequate defences that amount to nothing more than a shorter rail line towards conviction, particularly for the indigent innocent. Being convicted of a crime one is innocent of is a living nightmare. In whatever way the nightmare unfolds, it is a nightmare in which the silent screams of the innocent reverberate throughout the country. If you listen carefully, the injustice could chime as close as your nearest courthouse.

If asked, some people might be hard pressed to define justice, but the following stories give a startling description of injustice and its grim reality as it wades its way through the country we so unreservedly call "the land of freedom".

For instance, in the disquieting case of Herrera $v$. Collins, ${ }^{1}$ Leonel Herrera, a Texas death row prisoner, appealed his conviction to the U.S. Supreme Court on the grounds of newly discovered evidence that he believed proved his innocence. In his opinion denying the petition, Chief Justice William Rehnquist wrote that the execution of an innocent person would not necessarily violate the U.S. Constitution.

A more surprising element in the matrix of wrongful convictions are false confessions. Indeed, why would anyone make a false confession? In 2011, Helena, Montana resident Berry Beach was released from prison after 28 continuous years for the 1979 murder of his high school classmate, Kim Nees, a murder he confessed to but did not commit. Steven Drizin, a criminal law professor at Northwestern University School of Law and the director of the Center on Wrongful Convictions, studied more than 250 cases of proven wrongful convictions. He describes for USA Today how some murder 
investigators prematurely presume the guilt of a suspect and in their zeal to prove their own hunch they will zealously pursue a confession (Adams, 2011). Still, why would anyone confess to a crime they are innocent of? Drizin describes an eerie sounding practice wherein investigators begin to make direct or implied threats of long sentences combined with promises of leniency.

Promises of leniency are what turned an innocent 14-year-old Chicagoan named Terrell Scott. After twelve hours of intimidation by burly white officers standing over him and lurching in his face, being illegally refused an attorney, and being deprived of his right to call home, Scott readily confessed. These practices became so routine in Chicago that the Windy City was dubbed "The False Confession Capitol of the U.S." Chi-town has twice the number of false confessions as the U.S. federal system (False Confession Capital, 2012).

Like Scott's, the vast majority of false confessions are made by young black men. Scott was arrested at fourteen and was promised that he could go home to his mom if he simply confessed. When he complied, he did not go home that night as promised. In fact, Scott did not go home until he was thirty-four years old. As has been shown in many cases, investigators supplied Scott the specific details of the case to aid the so-called validity of the confession. Thank goodness for checks and balances; the courts have overturned 85 of Chicago's confession cases since 1989, in large part due to investigations by the New York-based Innocence Project. In some of the more flagrant cases prosecutors ignored exculpatory evidence, including concrete DNA evidence (False Confession Capital, 2012). Disquieting to say the least.

According to University of Virginia law professor Brandon Garrett, author of the 2011 book, Convicting the Innocent, of the 250 cases he reviewed, 40 of the confessions contained details for crimes they did not commit (Adams, 2011). Not one of the confessions was sufficiently recorded for outside scrutiny. One defendant, Beach, was sentenced to 100 years in prison. Scott was sentenced to fifteen years to life. The U.S. Supreme Court estimates that 94 to 97 per cent of criminal cases end in plea deals, where people must at least partially admit guilt ${ }^{2}$ (Prison Legal News, 2012b). In a criminal justice system that relies so heavily on admissions of guilt, any undue influence by authorities is cause for concern.

These are extreme sentences, particularly for an innocent person. Now imagine a wrongful conviction resulting in a death sentence. As of 1998, 
the latest data accessible to the authors, there have been 75 known cases of people wrongfully sentenced to die in America (McCormick, 1998).

Chicago's death row is where Dennis Williams and Verneal Jimerson sat for 18 years. They, along with two others, were convicted of the heinous abduction and bloody murder of a young and loving couple. DNA finally cleared the two black men. Yet, allegations of racial discrimination - among police, prosecutors and jurors - continue to muddy what residual of trust blacks have of Chicago's justice system.

In fact, with blacks disproportionately subject to arrest in America (one of every four), closely followed by Latinos, minorities have long felt that they are the cash cow of corrections, a misnomer for the U.S. prison system. The 1980 case of Clarence Bradley, a black American, accused of killing Cheryl Dee Ferguson, a blonde, hazel-eyed Texas student, only serves to add credence to this belief. A white officer allegedly told Bradley and a white janitor that one of them would hang for the murder. The white officer then turned to Bradley and said plainly, "Since you're the nigger, you're elected". After a long and dark ten-year struggle, it was proven that prosecutors suppressed exculpatory evidence against Bradley and he was eventually freed (McCormick, 1998; Radelet et al., 1992).

In California, a false confession and racial prejudice converged to make for one of the Big Bear's most recent egregious cases of injustice. Brian Banks had aspirations of becoming a professional football player. With growing interest from the National Football League, his aspirations were a real possibility. The 6'4', 225 pound, 16-year-old had big dreams. But those dreams were quickly dashed when he was falsely accused of rape and facing a sentence of 41 years to life. With little or no investigation, his public defender advised Banks to plead guilty because a jury of his so-called peers would likely convict him because of his size and the colour of his skin.

He was given just ten minutes to make a decision that would affect the rest of his life. All too familiar with the most likely outcome for black Americans in U.S. jury trials, Banks, despite his innocence, could not muster the faith needed to proceed with trial. He pleaded guilty for a lesser sentence. After being cleared later, when the victim came forward to admit she lied, the case went national (Levinson, 2012; Powers, 2012).

In May 2012, Northwestern University joined the University of Michigan to conduct a study on wrongful convictions. Of the 900 men studied, half were black, and the vast majority of their convictions were due to faulty 
eyewitness identifications, particularly in sexual assault cases (Levinson, 2012). The fact that eyewitness testimony cannot always be trusted was drawn to public attention earlier in this century by Harvard's professor of experimental psychology, Hugo Musterberg, who staged a "shooting" in his classroom to prove to sceptical students that witnesses to the same event do not tell the same story (Radelet et al., 1992).

Leslie Stahl, the grey-haired anchor for the news magazine 60 Minutes, was shown various tricks used by law enforcement in eyewitness cases and a slew of common mistakes were revealed as to how flagrant errors are made by earnest victims in police line-ups. When Stahl pointed out the face of the man whom she had seen moments before in a video, she was certain she had identified the right person. However, the only thing that was certain was that she had picked the wrong person (False Confession Capital, 2009). As simple as that, a life can be destroyed. These are facts with which we must live in a fallible world. The only remedy to reduce mistakes in such an error-prone environment is to proceed with caution, scrutinizing the evidence, asking hard questions and making sure that in the task of our civic duty, guesswork, conjecture and above all, prejudice is absent, particularly among those that show such inclinations in a jury panel.

Oregon recently lent us hope by being the first state in the nation to require specific guidelines for trials involving eyewitness identification. After reviewing the latest science, past errors, police and prosecutorial misconduct, new standards were ordered. Oregon admissibility guidelines now require that police line-ups be conducted by someone who is blind to the identity of the true suspect; others in the line-up must resemble the physical description given by the witnesses and photos of potential suspects must be shown one at a time, not in groups. Police and prosecutors must also declare the circumstances for which they obtain any witness descriptions or identifications. For instance, in the Oregon case that spawned these new guidelines the witness had been heavily medicated by doctors prior to police suggesting who they believed the perpetrator was (Murphy, 2012).

Another path to wrongful convictions is mistaken or charlatan expert witnesses. Such was the case with 28-year-old Glen Dale Woodall, a West Virginia cemetery worker. Woodall was accused, convicted, and imprisoned for the brutal kidnapping and rape of not one, but two women. $\mathrm{He}$ was sentenced to two life sentences and an additional 325 years to cement an already sealed fate of death behind bars. The linchpin in Woodall's 
conviction was not hard evidence, such as clothing from one of the victims or possession of property that belonged to one of the victims, or even an eyewitness. It was the state's medical examiner, Fred Zain, who testified, based on his personal experience, that Woodall's semen matched that of the specimen found on both victims.

Expert witnesses are often afforded nearly unquestioned credibility in court hearings with juries. They are believed to be totally impartial, infallible and on the exclusive side of science, nothing more. But as renowned defence attorney Thomas Mesereau, Jr. was quoted in his 2007 defence of music producer Phil Spector, the prosecutor's office "has the sheriff's department; the crime lab; the coroner's office. Their forensics experts [are all] paid for by the taxpayer". They are by nature of the business hired guns that want to continue to be hired, again and again. And to express balance to what are often infinite resources by the state, Mesereau stated: "The prosecutor is used to bowling over a poor defendant... When they occasionally run into a wealthy defendant... what [the wealthy defendant buys] is fairness" (Deutsch, 2007).

The expert testimony of medical examiner Zain not only locked Woodall away for life but also hundreds of other rape and murder defendants for the state of Virginia and later Texas. The problem was that Zain was flat out wrong in the majority of his "expert" opinions. After nearly five years of incarceration, Woodall's attorney took a shot in the dark and had a DNA test of Woodall's semen compared to the specimen held in evidence. Woodall's innocence was conclusive.

The West Virginia supreme court later ordered an examination of Zain's expert testimony in some 4,500 other criminal cases in two states. The result was that Zain's testimony was systematically and scientifically deficient. The court made the following ruling: "Any testimony or documentary evidence offered by Zain, at any time, in any criminal prosecution, should be deemed invalid, unreliable and inadmissible" (Abu-Jamal, 1995). According to a 2003 U.S. Justice Department report, some 3,000 criminal cases were thought to be affected by flawed science and skewed expert testimony. During that same period approximately 13 lab technicians across the country had made significant scientific errors that tainted criminal prosecutions (Abu-Jamal, 1995).

Following the May 2012 study of wrongful convictions jointly conducted by Northwestern University and the University of Michigan, research 
concluded that an unacceptable number of convictions are being caused by police and prosecutorial misconduct, or what the average person might call lying and cheating (Gross, 2012).

The annals of wrongful convictions are replete with cases of prosecutorial misconduct. In a 2010 study conducted by the Northern California Innocence Project at the Santa Clara University School of Law (a Veritas Initiative), research revealed a litany of preventable errors in the court arena. This comprehensive study of judicial findings detailed more than 700 cases of prosecutorial misconduct that resulted in the innocent being wrongfully convicted and some otherwise solid cases being compromised and thrown out. A summary of their findings revealed:

- In 102 cases, courts found that prosecutors committed misconduct. Courts found 130 instances of misconduct in those 102 cases.

- In 26 of the cases, the findings resulted in the setting aside of the conviction or sentence, mistrial, or barring of evidence.

- In 76 cases, the courts nevertheless upheld the convictions, ruling that misconduct did not alter the fundamental fairness of the trial, yet misconduct did occur.

- In 31 other cases, the courts refrained from making rulings on the allegations of prosecutorial misconduct, holding instead that any error would not have undermined the fairness of the trial or that the issue was waived. Still, misconduct was present (Veritas, 2010).

A summary, in pertinent part, of the findings from 1997 through 2010 showed that in more than 800 cases, courts found that prosecutors committed misconduct. In 202 cases, the finding resulted in setting aside the conviction or sentence, mistrial or of evidence. In more than 800 cases of misconduct, 107 prosecutors were found to have committed misconduct more than once, two were cited for misconduct four times, two were cited five times and one prosecutor was cited for misconduct six times. Prosecutors who committed misconduct multiple times accounted for nearly a third of all cases of misconduct (Veritas, 2010).

Misconduct in these cases included failure to turn over favourable evidence to the defence, presenting false evidence, engaging in improper examinations, making false and prejudicial arguments, violating defendants' Fifth Amendment right to silence, and discriminating against minorities in 
jury selection. In all, there were 34 findings of misconduct in these cases, including six findings that prosecutors failed to turn over favourable evidence to the defence. In some cases, the rulings came in the midst of trials and in others the rulings came years after conviction.

An estimated 700 to 1,000 drug prosecutions were also dismissed or dropped because prosecutors in the San Francisco District Attorney's Office failed to disclose damaging information about a police drug lab technician. In May 2010, Superior Court Judge Anne Christine Massullo found that prosecutors violated the constitutional rights of a vast number of defendants by failing to disclose to defence attorneys the problems relating to the cocaine-skimming drug technician. The judge found that a memo written by deputy district attorney Sharon Woo, expressing concern that the lab technician was an unreliable witness, proved that prosecutors "at the highest levels of the District Attorney's Office" were well aware of the situation, but this crucial information was never forwarded to the defence attorneys involved in these cases that relied on the technician's work (Veritas, 2010).

The pattern of corruption and lack of integrity continued in the federal prosecutions brought against executives of California-based Broadcom Corporation. In 2009, U.S. District Court Judge Cormac Carney dismissed charges against Broadcom's former chief financial officer, William Ruehie, and company cofounder, Henry T. Nichols III, on the grounds that the prosecutor, Andrew Stolper, intimidated witnesses. The charges included drug trafficking, possession of large amounts of illegal substances, along with a number of illegalities related to their enterprise. In 2010, Carney dismissed additional charges against Nichols (Pfeifer, 2010; Ridolfi and Possley, 2010; Veritas, 2010).

In November 2010, more than a quarter century after Bobby Maxwell was convicted and sentenced to life in prison, the Ninth Circuit U.S. Court of Appeals ordered prosecutors to release him or give him a new trial. The reason cited was due to appalling prosecutorial misconduct (Savage, 2012). In the decision authored by appeals court jurist Richard Paez, the court found that the prosecution had failed to turn over impeachment evidence to Maxwell's lawyers and failed to correct false testimony from its star witness, infamous jailhouse informant Sidney Storch. Judge Paez wrote, "The prosecutor's failure to disclose this impeachment evidence undermines confidence in the outcome of Maxwell's trial... The prosecutor's failure to correct Storch's testimony... was prejudicial". ${ }^{3}$ 
The prosecutor assigned to the case was former Los Angeles deputy district attorney Sterling Norris. The appeals court complained that Norris had failed to disclose evidence of benefits given to Storch and when Storch lied about them, Norris failed to correct his false testimony. The finding was the second case in which Norris has been cited for misconduct. The decision ordering a new trial or for Maxwell's release is among 26 court rulings in 2010 identified by the Veritas Initiative where prosecutorial misconduct was deemed harmful, that is, the conduct undermined the integrity of the convictions, caused mistrials, or evidence to be barred, and cost taxpayers millions in court and custodial expenses.

Maxwell was arrested in 1979 and charged with the murders of ten men in downtown Los Angeles. After a nine-month trial, Maxwell was convicted of two counts of murder and one count of robbery, largely stemming from the testimony of Storch, who claimed Maxwell confessed to him in a jail cell. The only physical evidence against Maxwell was a palm print found on a public bench near the body of one of the victims, a public bench that thousands of other Los Angeles residents had also touched.

"Here, the prosecution itself admitted that the evidence against Maxwell was weak, that Maxwell had consistently maintained his innocence, and that the police testimony about the date of the palm print was speculative... The prosecution failed, however, to disclose multiple pieces of impeachment information that could have been used to undermine the credibility of Storch", the judge opined in Maxwell. In 2004, the Ninth Circuit U.S. Court of Appeals also set aside the murder conviction and life sentence of Timothy Gantt, also due to Norris's failure to turn over evidence to the defense. ${ }^{4}$

The widespread problem of police misconduct, to the extent of absolute corruption, could not be better exemplified than that of the Los Angeles Police Department Rampart Scandal. Think fictional tales such as Training Day, on meth, Lakeview Terrace, on steroids, or $C R A S H$, on rocket fuel. The story of scandal had been years in the making before it all unravelled in 1999, when elite officer Rafael Perez, who had been sponsored to enter the CRASH unit (Community Resources Against Street Hoodlums). Sponsorship by a respected member of the CRASH team was required before an outsider could enter into the intricacies of the exclusive network. Sammy Martin, a close friend of Officer David Mack, vouched for Officer Perez. Among the more notable crimes ascribed to the unit were robbing suspects and citizens, at least one bank robbery (by Officer Mack), collaborating 
with street gangs in criminal activity. Some officers, such as Mack, were literally gang members themselves. Yet, most relevant to this paper are their crimes involving the framing of suspects.

Members of the unit routinely planted drugs on suspects, enemies and citizens. They shot unarmed suspects and planted what they called "drop guns" on them. Adding to their long list of crimes, they conspired to falsify reports to protect the criminal unit. While citizens, suspects, and defendants had been complaining about the unit's illegalities for years, it was not until repeated thefts from the L.A.P.D. evidence locker, including nine pounds of powdered cocaine that went missing, that Perez came under suspicion (Reavill and Brown, 2000). The investigation peeled off one criminal act after another, layer by layer, involving other officers, including a sergeant. When Perez was finally arrested and agreed to "sing like a bird" on his cohorts, investigators were astounded by a song that lasted nearly 14 hours before they wearily concluded the session for the night (Boyer, 2001).

The Los Angeles Times called it "the worst corruption scandal in L.A.P.D. history". Indeed, it was worse than Rodney King in 1991, worse than a history of racial profiling and repeated accusations of racism since its 1920s chief, Louis Oaks, who was a verified member of the Ku Klux Klan. Now, under the leadership of a black man, Bernard Parks, the department was experiencing another dark era (Boyer, 2001).

The most heart-wrenching event of evidence planting was the case of 19-year-old Javier Francisco Ovando. In 1996, Officer Perez and his partner, Nino Durden, were on stakeout. Ovando had walked up and accidentally surprised the officers, who responded with a hail of bullets. Ovando was critically struck in the head and chest before they realized he was unarmed. As Ovando lay bleeding out, Officer Durden, according to Officer Perez, placed a drop gun near Ovando. Their cover story was that Ovando was a vicious, gang-banging cop killer who had burst in on their post with the intent to assassinate them. Ovando, a Honduran who speaks very broken English, survived the encounter, but was paralyzed as a result and confined to a wheelchair. During trial for attempted murder of the officers, among other charges, he was convicted after Officer Perez convincingly testified against him. The judge threw the book at Ovando for the blatantly irreverent crime and for his apparent lack of remorse.

Upon the revelation that it was the officers who were in the wrong, it was the police department heads, not the district attorney's office or a defence attorney, 
who sought Ovando's immediate release. According to Officer Perez, Ovando was just one of many such victims. A Blue Ribbon Rampart Review Panel was created in 2003 to investigate what went wrong. Among numerous criticisms, the panel found that there existed a long-time lack of sufficient checks to prevent officers from lying or fabricating evidence (City Task Force, 2006).

As the lawsuits go forward, it is estimated the city will be forced to pay hundreds of millions for its officers' criminal activities. Over 100 criminal cases have been overturned thus far, and an estimated 4,000 more cases may still be affected. In 2002, in an extraordinary measure to regain public trust in the justice system, following the Rampart Division scandal, Governor Gray Davis signed into law Senate Bill 1391. This bill gives prisoners sentenced to life without the possibility of parole or death the right to seek all discovery materials that a defendant would have been entitled to during trial for his or his attorney's review, because, in spite of Officer Perez's confessions, no one really knows the true extent of the damage.

In his signing statement accompanying SB 1391, Davis wrote, "As governor, I strongly support the hard working men and women of law enforcement. However, nobody is above the law and in the rare cases where governmental officials deceive the courts, there must be appropriate remedies" (Capitol Connection, 2002, p. 3).

Officer Perez, for his part, stated that "The line between right and wrong became fuzzy and indistinct... I stepped over that line landing with both feet sometimes on innocent people..." (Reavill and Brown, 2000). The L.A.P.D. was placed under a federal consent decree or what we call formal probation (L.A.P.D., 2006).

As the fallout of the L.A.P.D. scandal waned, the Los Angeles County Sheriff's Department made headlines of its own secret, illegal activities that deepened distrust within the community, a community of primarily residents or colour. In what they called "Operation Any Booking", there was a competition among the rank and file to arrest the most people within a specific 24-hour period. There was also "Operation Vehicle Impound", a competition to seize the most cars. Just good ole boys having fun. The teams involved sheriff's deputies from numerous cities: Lakewood, Bellflower, Paramount, Artesia, and, of course, Los Angeles, to name a few (Glover and Lait, 2007). It can be safely assumed that with most impounds an arrest occurred. So the question with this unethical, and potentially illegal practice is, was every arrest above board? 
Los Angeles Public Defender, Michael P. Judge, told the Los Angeles Times that he worried the games might prompt deputies to make illegitimate arrests to boost their statistics. And when we think about it, what would the law enforcement community be without criminals? What would the drug enforcement community be without drugs to interdict? That is to say, if they were to completely eradicate the drug market, would that not prove adverse to them? What would prisons be without repeat offenders? Could that explain why prisons have such a high recidivism rate, while rehab centres and religious institutions have a much higher success rate in addressing the same human foibles? It is, then, not inconceivable that within these law enforcement agencies thrives an attitude condoning such underhanded practices for, among other motives, job security. The games were exposed by a leaked email of management officials who appeared to promote the competition (Glover and Lait, 2007).

Injustice manifests itself in court errors, biases and interference as well. The 1996 case of Armenia Cudjo is an example of how an erroneous ruling can make the difference between a wrongful conviction or a deserved acquittal. Armenia Cudjo was convicted of viciously murdering Armelia Produka, whose partially clad body was discovered in her apartment in the California desert community of Littlerock. A hammer stained with blood residue was found nearby. There was evidence that Armenia Cudjo knew the victim, and was at her home earlier in the day. He confessed to having sex with Produka, but adamantly denied having killed her (Egelko, 2012).

Armenia Cudjo told police that he believed his brother, Gregory Cudjo, was Produka's killer, adding that he confessed to committing the crime. A physical description given by Produka's younger brother fit Gregory Cudjo. During trial, over a year later, while Armenia Cudjo waited in the county jail, John Culver, a neighbour, told the sheriff, the trial lawyers, and anyone who would listen, that while Armenia Cudjo was being detained in jail for questioning, Gregory Cudjo had confessed that he had killed Produka. At trial the judge refused to allow Culver to testify (Egelko, 2012). The question in such cases is why? Why deprive a jury of any of the facts? Yet, decisions like this are common in courts all across the nation.

The Ninth Circuit Court of Appeals subsequently ruled that Armenia Cudjo was denied the right to present a defence. When given the opportunity in 2008, Gregory Cudjo confessed to the killing and confirmed that he had previously admitted to killing Produka. After 12 years on death row, Armenia Cudjo was finally vindicated (Egelko, 2012). 
Not so fortunate was California prisoner Omer Gallion. Gallion was assigned to the docket of U.S. District Court judge Percy Anderson, in the Central District of the Golden State. Judge Anderson has a history of allowing potentially meritorious petitions to grow stale - for years. Gallion filed a habeas corpus petition claiming he had been wrongfully convicted. A magistrate judge recommended that Gallion's petition be granted. However, Gallion died in prison six years later, in 2010, while awaiting for judge Anderson to act. In July 2011, a legal publication reported that judge Anderson had sat on habeas petitions for periods ranging from five to eight years after magistrate judges had recommended relief (Prison Legal News, 2012a).

While defence attorneys can hardly force a judge to be fair, it is when defence attorneys themselves drop the ball that the situation is exacerbated for the defendant. The American mainstream press has repeatedly reported on stories of defence attorneys sleeping in court, appearing in court inebriated or even high, but it does not end there.

Ponder the death penalty case of Cory Maples: the Alabama death row prisoner lost his right to appeal after the law firm representing him misplaced his court motion somewhere in their own mailroom. As a result, Maples, who was convicted in 1997 of a double murder, was barred from appealing his conviction. And while Maples maintains his innocence, at least in part, the courts did not want to hear it; he was late and lacked diligence in the pursuit of proving his case, the courts repeatedly opined. However, it was not the neglect of Maples, but that of his attorneys. Still, as representatives of the client, anything that the defence counsel does is owned by the client, even if he is locked up thousands of miles from his attorneys and has no control whatsoever over what the attorneys do. The attorney and client, as the court proceedings go, are one and the same.

Yet, in a rare exhibition of compassion (and fairness), the US Supreme Court gave Maples a break. ${ }^{5}$ Writing for the majority, in a 7-2 decision, Justice Ruth Bader Ginsberg said, "No just system would allow a missed deadline to be held against the inmate... Maples was disarmed by extraordinary circumstances quite beyond his control". He was convicted of murdering two of his companions after a night of drinking, yet, as Ginsberg noted, "His inexperienced and underfunded attorneys failed to develop and raise an obvious intoxication defense, did not object to several egregious instances of prosecutorial misconduct and woefully unprepared for the penalty phase of his trial". 
Justices Antonin Scalia and Clarence Thomas dissented and complained, among other issues, that such a ruling would open the flood gates to other prisoners, who, perhaps, were neglected or abandoned by their counsel. The ruling was limited to Maples (Liptak, 2012). It is here where the variance between having an overwhelmed and underfunded public defender or well paid and enthusiastic court advocate can make the difference between life and death, or freedom and life imprisonment.

There are many critical stages in any criminal case. Perhaps one of the most critical is when there is a jailhouse informant, otherwise known as a snitch. The case of Maxwell, above, offered a glimpse of the problems with snitches. They almost always have an ulterior, personal motive; they are highly unreliable and all too often, the terms for which they are testifying (i.e. whether they are receiving unknown, untold promises, is hardly ever fully revealed). The details of these and other problems were enumerated in yet another epic scandal involving the Los Angeles criminal justice system.

The report of the 1989-1990 Los Angeles County grand jury, Investigation of the Involvement of Jailhouse Informants in the Criminal Justice System in Los Angeles County (IIJI), began, "On or about October 24, 1988, [when] a jailed informant demonstrated for the Los Angeles County Sheriff's Department how he and others could obtain confidential information and then fabricate confessions of fellow prisoners". Thousands of pages of documents and other evidence were reviewed by the grand jury, over 120 witnesses testified, and 147 exhibits were introduced into evidence. Witnesses included several other jailhouse informants, judges, district attorneys and prosecutorial staff, county and state public defenders and members of the bar, police and Sheriff's department, custodial employees and private citizens (IIJI, 1990, p.1).

As in prosecutorial and police misconduct cases, the extent of the cases adversely affected may never be known. What is known is that a small army of jailhouse informants played the system and the taxpayers of Los Angeles County. Various jailhouse informants, in and out of custody, testified to their own schemes and misconduct. The jailhouse informants central to the grand jury investigation had been charged with a number of crimes ranging from armed robbery, to rape and even murder, and every crime in between. Nearly every informant had an inclination toward recidivism. One informant was convicted of two counts of arson in 1975, convicted in 1979 for attempted rape, rearrested in 1985 and thereafter convicted of multiple counts of rape, kidnap, robbery and other sexual offenses (IIJI, 1990, p. 9-10). 
Whatever the individual motive of the jailhouse informant, courts have long recognized "the potential for untrustworthiness which is inherent in such testimony because of the strong inducements to lie or shape testimony in favor of the prosecution". Rarely is a jailhouse informant's willingness to testify based on his moral leanings, repugnance of a particular crime, or the defendant's lack of remorse. Jailhouse informants expect some reward for their testimony, and in some cases they demand it (IIJI, 1990, p. 10).

The benefits can range from extra servings of food to lighter sentences. For example, for past cooperation, an officer arranged for an informant's transfer to a cell with a TV, coffee pot and other amenities not available to other prisoners. Another informant asked for and was granted a request that his incarcerated girlfriend with a million-dollar bail be released on her own recognizance. And yet another informant who testified for the prosecution had his assault charges on a police officer dropped, was allowed to plead guilty to the remaining robbery charges and received a shortened sentence of three years. And still another informant testified that he received several thousand dollars and housing expenses once released from custody; for at least eight months he received free rent valued at \$525 a month and \$200 a month in other living expenses (IIJI, 1990, p.13-15).

Many informants testify repeatedly for favours. One informant claims that he testified for the prosecution in Los Angeles County ten times. The methods used to manipulate fellow prisoners and professionals alike is both astounding and frightening. Several informants claim that they collaborate with each other to deceive vulnerable prisoners, exploit the system and manipulate law enforcement. During the past ten years, an appalling number of instances of perjury and other falsifications to law enforcement were described by informants (IIJI, 1990, p.21-24).

Informants also described their knowledge and familiarity with the system and people in the district attorney's office. One informant said he would call prosecutors he knew and tell them the case numbers and names of defendants the prosecutor was pursuing. He would then seek leniency by offering information. One informant said he would call the coroner's office, or other city departments, pose as a prosecutor and ask particulars to learn the details necessary for personal leverage. Several testified they obtained copies of police reports, case files and photographs of defendants and victims to use for their advantage (IIJI, 1990, p. 28-30).

Other informants claimed they were approached by police and sheriff's deputies and asked to "cell-up" with certain individuals in order to strike up 
trust and conversations that would enhance the government's case against other prisoners. More informants claimed that police asked them how to burglarize a home or how the drug dealing game works; they gave them what they wanted and became part of the official informant network. Others were forced in by constant announcements directed at prisoners over the public address system in the jail in order to make it appear that they were informants. Once labelled by the jail population as a snitch, his safety became an issue, forcing him to seek custodial protection. Some informants claim they were simply placed in the cell of a defendant for a few days without being asked to do anything. Once a record is created that the informant and defendant shared a cell for a period of time, the police would simply provide the informant with critical details of the case to later be used by the informant in court. In one case, an informant offered to testify for the district attorney. The district attorney found the informant's testimony lacking in credibility, so the informant offered to testify for the defence, who also declined (IIJ, 1990, p.18).

In 1984, Federico M. Macias was sentenced to death in Texas. He was vindicated in 1993 when a former cellmate admitted in federal court he had perjured himself. Testifying before a congressional subcommittee after his release, Macias said, "My case shows that the system can work. But it also shows that, when it does work, it is largely because of luck" (Radelet et al., 1992).

\section{ENDNOTES}

506 U.S. 390 (1993).

2 See Missouri v. Frye, 132 S.Ct. 1399 (2012) and Lafler v. Cooper, 132 S.Ct. 1376 (2012).

3 See Maxwell v. Roe, 628 F.3d 486 (2010).

Gantt v. Roe, 389 F.3d 907 (2004).

5 Maples v. Thomas, 132 S.Ct. 912 (2012).

\section{REFERENCES}

Abu-Jamal, Mumia (1995) Live From Death Row, Brattleboro (VT): Westley Publishing Company.

Adams, John (2011) “Police errors fuel false confessions”, USA Today, p. A3 - December 27.

Antelope Valley Press (2006a) "City task force urges LA.P.D. reforms", pp. A4, A6 July 13. 
Antelope Valley Press (2006b) “L.A.P.D. dragging its heels on consent decree”, pp. A4, A6 - July 13.

Boyer, Peter J. (2001, May 21) "Bad Cops", The New Yorker - May 21. Retrieved from <http://www.newyorker.com/archive/2001/05/21/010521fa FACT? currentPage $=9>$.

Capitol Connection (2002) Judicial Council of California, Administrative Office of the Courts, Office of Governmental Affairs, 4(9): 3.

County of Los Angeles (1990) Investigation of the Involvement of Jailhouse Informants in the Criminal Justice System in Los Angeles County, Los Angelas (CA). Retrieved from <http://www.ccfaj.org/documents/reports/jailhouse/expert/1989-1990\%20 LA\%20County\%20Grand\%20Jury\%20Report.pdf > .

CBS News (2012) "False confession capital of the world", 60 Minutes - December 9.

Deutsch, Linda (2007) "Spector's case raises issues of resources in high profile trials", Antelope Valley Press, p. A8 - November 28.

Egelko, Bob. (2012) "Conviction overturned for death row inmate", San Francisco Chronicle, p. C3 - October 1.

Gross, Samuel (2012). KCRW Radio News [interview] - May 21.

Grover, Scott and Matt Lait (2007) "For deputies, arrest can be a contest" Los Angeles Times, p. Al, p. A15 - October 4.

Levinson, Laurie (2012) KCRW Radio News [interview] - June 1.

Liptak, Adam. (2012) "Justices rule for inmate after mailroom mix-up", The New York Times, p. A11 - January 19.

McCormick, John (no date) The Wrongfully Condemned. Last retrieved 18 March 2013 from <http://www.michellehenry.fr/webquests/Death\%20Penalty/The $\% 20$ Wrongly\%20Condemned.htm>.

Murphy, Kim (2012) "Oregon raises the bar on eyewitness IDs", Los Angeles Times, p. A20 - December 2.

Pfeifer, Stuart (2010). "Broadcom drug case unravels; Prosecutors asked judge to dismiss trafficking charges against Henry T. Nichols III, the Chip Maker's co-founder", Los Angeles Times - January 8.

Powers, Ashley (2012) "Decade-long nightmare ends for man falsely accused of rape", The Fresno Bee, p. Al - May 25.

Prison Legal News (2012a) p. 18 - September.

Prison Legal News (2012b) p. 40 - October.

Radelet, Michael, Hugo Adam Bedau and Constance Putman (19992) In Spite of Innocence: The Ordeal of 400 Americans Wrongly Convicted of Crimes Punishable by Death, Boston: Northeastern University Press.

Reavill, Gil. and Justine Brown (2000) "The dirtiest cop alive", Maxim, p. 188 November.

Ridolfi, Kathleen and Maurice Possley (2010) Preventable Error: A Report on Prosecutorial Misconduct in California 1997-2009 - October.

Savage, David (2012) "High court upholds ruling overturning 'Skid Row Stabber' verdicts", Los Angeles Times - January 10. Retrieved from <http://articles.latimes. com/2012/jan/10/local/la-me-skidrow-stabber-20120110>.

Veritas Initiative (2010) Veritas Initiative Report - September 22. Retrieved from $<$ http://www.veritasinitiative.org/>. 


\section{ABOUT THE AUTHORS}

Dortell Williams is a California prisoner who has been incarcerated for 22 years, during which he has earned a paralegal certificate, an associate of arts degree and taught himself Spanish. He mentors at-risk youth at his facility and through correspondence. He is also the author of many articles regarding imprisonment. Dortell can be contacted via email at dortellwilliams@ yahoo.com or by mail at the following address:

\section{Dortell Williams 45771/A2-206 \\ P.O. Box 4430 \\ Lancaster, California 93539 \\ USA}

Anthony "Tony" Majoy is a 75-year-old who has spent the last 24 years incarcerated for a crime he maintains he did not commit. He works to educate the public about wrongful convictions as his appeals take their slow, winding course. Tony can be contacted at:

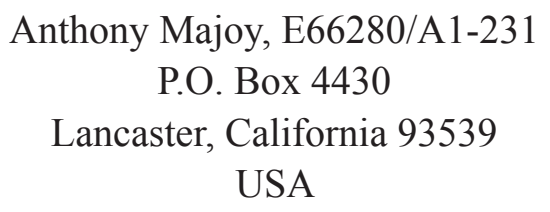

Both prisoners are confined at the California State Prison in Los Angeles County, where they met and began collaborating against draconian sentences such as life without the possibility of parole or what they call the death penalty on the instalment plan - a sentence they both share. 